\title{
БАР’ЄРИ ПЕДАГОГІЧНОГО СПІЛКУВАННЯ ВИКЛАДАЧА I СТУДЕНТА У МЕДИЧНОМУ УНІВЕРСИТЕТІ
}

\author{
A. V. Chornomydz \\ I. Horbachevsky Ternopil National Medical University \\ BARRIERS OF PEDAGOGICAL COMMUNICATION BETWEEN A \\ LECTURER AND A STUDENT IN THE MEDICAL UNIVERSITY
}

\begin{abstract}
Анотація. У статті проаналізовані основні психологічні бар’єри у спілкуванні між викладачем та студентом. На основі даних літератури розглянуто причини виникнення бар’єрів педагогічного спілкування, їх характерні особливості та можливі шляхи вирішення описаних проблем. Основною ідеєю статті є те, що професійний педагог поєднує у собі не лише знання конкретного предмета, але і педагогічну майстерність, тобто вміння увійти в контакт зі студентом, зацікавити його, виховати потрібні якості, перетворити студента з об'єкта навчання у суб’єкт. Багато залежить і від особистих здібностей викладача, його педагогічної інтуїції. Але, навіть володіючи викладацьким талантом, необхідно постійно вдосконалювати свою педагогічну майстерність.

Продуктивне спілкування в системі викладач - студент відбувається лише за умови організації педагогічного процесу на демократичних засадах, позитивного ставлення викладача до студентів, захопленості спільною творчою діяльністю. Тому при організації взаємодії зі студентами на практичних заняттях викладачам варто використовувати найбільш продуктивні інтерактивні методи навчання, збільшувати зацікавленість студентів-медиків до дисциплін, які вони вивчають, посилювати мотивацію студентів на здобуття освіти.
\end{abstract}

Ключові слова: педагогічне спілкування; викладач; бар’єри спілкування; система викладач - студент.

Abstract. The article adduces the main psychological barriers in communication between a lecturer and a student. On the basis of literature data, the reasons of the barriers of pedagogical communication occurrence, their characteristic features and possible ways of solving the described problems have been considered. The main idea of the article is that a professional lecturer combines not only knowledge of a particular subject, but also pedagogical skills, that is, the ability to get in touch with a student, to interest him/her, to raise the necessary qualities, to transform a student from the object of study into the subject. It depends a lot on the lecturer's personal abilities and his/her pedagogical intuition. But even having the teaching talent, it is necessary to continuously improve personal pedagogical skills.

Productive communication in the lecturer-student system takes place only if the pedagogical process is organized on a democratic basis, the lecturer's positive attitude towards students, and enthusiasm for the joint creative activity. Therefore, organizing interaction with students in practical classes, lecturers should use the most productive interactive teaching methods, increase the interest of medical students in the disciplines they study, and increase the motivation of students to study.

Key words: pedagogical communication; lecturer; barriers of communication; lecturer - student system.

Вступ. У сучасних умовах реформування системи освіти в Україні перед багатьма вищими навчальними закладами виникає проблема підвищення якості освітнього процесу [8]. Традиційний підхід до вузівського процесу розглядає його як передачу знань, умінь і навичок, де один, який навчає, - передає, інші, які навчаються, - засвоюють, один інформує, інші - відтворюють засвоєну інформацію, один пред'являє вимоги, інші - їх виконують. При такому варіанті побудови навчання неможливо забезпечи-

(c) А. В. Чорномидз ти самостійність, творчість, ініціативу студентів. Формалізм у навчанні породжується тим, що педагогічний процес обмежується педагогічною дією, тобто має односторонній характер, що пригнічує активність і пізнавальну самостійність студентів [4].

Педагогічна діяльність - це діяльність не індивідуальна, а спільна. Вона завжди спільна вже тому, що в педагогічному процесі є обов'язково дві активні сторони: викладач і студент [7].

У процесі педагогічної взаємодії відбувається особистісне зростання, духовно-творче збагачення 
обох сторін. У межах цього процесу провідна роль належить викладачу, функції якого мають специфічні якості й ознаки, а особистісні психологічні характеристики здатні впливати як на навчальновиховний процес загалом, так і на особистісний розвиток кожного студента. У певному сенсі викладач є центральною фігурою у вищому навчальному закладі, йому належить і стратегічна роль у розвитку студента протягом професійної підготовки [1].

Незаперечний той факт, що всі знання і практичні вміння викладача можуть передаватися студентам лише завдяки живому й безпосередньому спілкуванню з ними [1]. Для багатьох викладачів очевидна істина: студенти нерідко переносять ставлення до викладача на предмет, який він викладає. На цих стосунках вибудовується складна й об'ємна піраміда навчання і виховання [7].

Педагог медичного вишу повинен бути різнобічно розвиненою особистістю, вміло поєднувати в собі якості викладача-предметника, вченогофахівця, фахівця-лікаря, організатора, новатора. Встановлено, що у професорів і доцентів найбільш сформовані конструктивні навички (планування i композиція матеріалу, постановка завдань), частково організаторські. 3 комунікативними - гірше (діють поведінкові стереотипи). Асистенти меншою мірою володіють конструктивними і організаторськими вміннями (скажімо, не завжди можуть організувати самостійну роботу студентів), але зате адекватно сприймають студентську аудиторію: позначається менше вікова дистанція [6].

Сучасний викладач повинен бути неординарною особистістю. Зробити самого себе, пізнати власний внутрішній світ і досягти досконалості педагогічних здібностей - важлива ланка в професійній підготовці майбутніх фахівців. Тому необхідно ще у педагогічному вищому навчальному закладі створити такі умови, які допомогли б кожному студенту знайти шлях самовдосконалення, професійного вигляду, індивідуального, інтелектуального, етичного, духовно-емоційного розвитку [4].

Мета статті - висвітлення основних проблем та бар’єрів у спілкуванні між викладачем та студентом, аналіз причин їх виникнення та пошук шляхів вирішення.

Теоретична частина. Процесу педагогічного спілкування, як свідчить педагогічна практика, властиві різноманітні труднощі, які ускладнюють сприйняття навчальної, наукової тощо інформації студентами, заважають їх пізнавальній діяльності, формуванню як гармонійних особистостей, профе- сійному становленню, унеможливлюють їх адекватні когнітивні, поведінкові тощо реакції. Такі труднощі у взаємодії викладача зі студентами кваліфікують як бар'єри і пов'язані з накопиченням та правильним узагальненням інформації щодо одне одного, залежать від рівня розвитку комунікативних умінь викладача та його здатності до спостережливості та вміння слухати, розуміти студента і впливати на нього завдяки переконанню, навіюванню, емоційній «заразливості», зміні стилів і рольових позицій спілкування, умінню долати суперечки та конфлікти [2].

Бар'єр - це психічний стан, який проявляється в неадекватній пасивності суб'єкта, що перешкоджає виконанню ним тих або інших дій. Бар'єр полягає в посиленні негативних переживань й установок - сорому, відчуття провини, страху, тривоги, низької самооцінки тощо [3]. Бар'єри спілкування - це труднощі в обміні думками, в досягненні взаєморозуміння і згоди між учасниками спілкування [2].

Протиріччя у вербальній та невербальній поведінці, а також у мотиваційно-ціннісному просторі сприяють виникненню бар'єрів спілкування між співрозмовниками, коли вони спричиняють взаємонепорозуміння, відчуженість один до одного, небажання спілкуватися [8].

Найбільш типовими «бар’єрами», які можуть суттєво заважати побудові педагогічної взаємодії між викладачем та студентами, $\epsilon[5,8]$ :

- «бар'єр» невідповідності настанов і мотивів. Цей бар'єр виникає перш за все у викладачів, які добре володіють матеріалом, готові використовувати різноманітні інноваційні методики, ділитися цікавими ідеями та власними роздумами із студентами, планують цікаві задуми на заняття, шукають інтересні факти, але, почавши заняття, викладач розуміє, що група байдужа, студенти неуважні, незібрані, невмотивовані й не бажають слухати та навчатись. Це дуже дратує, нервує педагога i, як наслідок, не вдається налагодити продуктивний контакт із групою $[5,8,9]$;

- «бар'єр» побоювання групи виникає у викладачів-початківців, які непогано володіють матеріалом, добре підготувалися до заняття, однак сама думка про безпосередній контакт зі студентами лякає їх, пригнічує творчу ініціативу, заставляє хвилюватись, забувати слова, порядок проведення заняття тощо [5, 9];

- «бар'єр» відсутності контакту виникає у широкої когорти викладачів, для яких важливою $€$ перш за все суха передача інформації, які не вмотивовані на контакт із студентами, а лише автоматич- 
но виконують свою роботу. Часто цей тип бар’єра часто виникає у молодих викладачів, які звикли доносити інформацію на конференціях чи конгреcax i не мають педагогічного досвіду. При цьому викладач заходить до аудиторії і замість того, щоб швидко й оперативно організувати взаємодію зі студентами, починає діяти автономно (наприклад, читає лекцію, не звертаючи увагу на реакцію студентів, на їх емоційний відгук, пише тему лекції на дошці тощо) [5, 8, 9];

- «бар'єр» звуження функцій спілкування відмічається в тих випадках, коли педагог враховує лише інформаційні функції спілкування, нехтуючи соціально-перцептивними, афективно-комунікативними, організаційними та ін. [5, 8, 9];

- «бар'єр» негативної настанови на академічну групу, яка інколи може формуватися на основі думки інших викладачів, що працюють із цими студентами або $є$ наслідком негативного досвіду педагогічного спілкування в минулому 3 даною групою або студентом [5, 8];

- «бар'єр» побоювання педагогічних помилок виникає тоді, коли викладач боїться, що не зможе відповісти на «каверзне» запитання студента, або вагається, чи правильно оцінює роботу студентів, переживає, що може запізнитися на заняття, не вкластися в час, забути матеріал тощо [9];

- «бар'єр» наслідування: молодий педагог намагається наслідувати манери спілкування, стиль діяльності авторитетного педагога, не враховуючи свої власні психологічні особливості, нехтуючи власною індивідуальністю [5, 8].

Також можуть виникати бар’єри спілкування, які притаманні будь-якій комунікативній взаємодії. Найбільш типовими серед них є такі:

- смисловий «бар'єр», як правило, пов'язаний 3 неадаптованим до рівня сприйняття студентів мовленням викладача, яке занадто насичене незрозумілими словами, науковими термінами, що використовуються без коментарів [9]. Це знижує їх інтерес студентів до матеріалу, створює дистанцію у взаємодії [2]. Окрім цього, одне й те саме явище (слово, фраза, подія) мають різний смисл для різних людей [5];

- моральний «бар'єр» стосується відмінності між людьми різного віку в засвоєних ними соціальних нормах і обмеженнях; що полягає у неприйнятті викладачами манер поведінки і спілкування, спрямованості інтересів, моди тощо. При цьому викладач у спілкуванні зі студентами часто порівнює своє покоління із сучасним, вказуючи на зниження моральних цінностей [5];
- інтелектуальний «бар’єр»-відмінності в рівні інтелекту, глибині передбачення і розуміння ситуації та проблем. Він часто виникає в спілкуванні з викладачем, який характеризується чітко вираженою спрямованістю на наукову діяльність, якщо йому не вдається адаптувати наукові знання та поняття до інтелектуально-пізнавальних можливостей студентів [5];

- ригідний «бар’єр» - відсутність гнучкості міжособистісних настанов, утруднення перебудови сприйняття, системи мотивів, емоційних відгуків у ситуації, що змінюється. Інерція, відсталість від реалій життя, звичні схеми спілкування характерні для тих досвідчених викладачів, хто не працює над самоосвітою, професійно не вдосконалюються, не бажають опановувати нові педагогічні методи [5];

- емоційний «бар'єр» є наслідком невідповідності настрою, негативних емоцій викладачів і студентів, що деформують сприймання, особливо під час заліків та екзаменів, відсутність емпатії, а також нездатність розуміти реакцію студентів, які перебувають у стані емоційного збудження та афективних реакцій $[2,5]$;

- естетичний «бар'єр», виникає через несприйняття співрозмовником зовнішнього вигляду, охайності одягу, особливостей міміки, зовнішньої привабливості, вишуканості рухів тощо, а також до педагогічного такту й етикету взаємин $[2,5]$.

У спілкуванні педагога виокремлюють також соціальний, психологічний, фізичний та інші бар'єри, котрі залежать від особливості організації взаємодії між викладачем та студентом [9]:

- соціальний «бар'єр» зумовлений домінуванням рольової позиції викладача в системі педагогічної взаємодії. Викладач навмисне демонструє перевагу над студентами і свій соціальний статус, підноситься над особистістю студента [6, 9];

- фізичний «бар'єр» пов'язаний з організацією фізичного простору взаємодії. Так, неправильно організований простір спілкування спричинює ізольованість викладача, який неначе віддаляє себе від студентів, намагаючись сховатися за стіл, стілець чи в куток [2, 9];

- морально-психологічний «бар'єр» виникає внаслідок принизливо-насильницьких дій щодо студентів. Прогнозування, своєчасне усунення такої напруги можливі за умови правильної оцінки викладачем ситуації [2];

- інтуїтивно-емоційний «бар'єр» постає як невідповідність емоційної настанови аудиторії. Тобто студенти ще до початку лекції чи практичного заняття вже негативно настроєні і не бажають брати 
участь у педагогічному процесі. Можливі шляхи усунення цього бар’єра: зміна емоційного настрою студентів цікавою розповіддю викладача, бесідою, яка несе відповідне позитивне забарвлення; використання ситуативних завдань тощо [2];

- кордон психологічного самозахисту є реакцією на гіпотетичну чи зумовлену попереднім досвідом можливість стати об'єктом кепкування, нетактовних зауважень студентів, інших викладачів [2].

Психологічні «бар’єри» спілкування виникають непомітно і спочатку можуть не усвідомлюватися викладачем, проте студенти сприймають їх одразу. Але якщо «бар’єр» закріпився, то й сам педагог починає відчувати дискомфорт, тривогу, нервовість. Цей стан стає стійким, заважає плідному контактові зі студентами та, зрештою, впливає на характер педагога - формує так званий «неправильний» педагогічний характер [5].

Поняття «професійний педагог» поєднує у собі не лише знання конкретного предмета, але і педагогічну майстерність, тобто вміння увійти в контакт зі студентом, зацікавити його, виховати потрібні якості, перетворити студента з об’єкта навчання у суб'єкт. Багато залежить і від особистих здібностей викладача, його педагогічної інтуїції. Але, навіть володіючи викладацьким талантом, необхідно вчитися педагогічного спілкування [5].

Піднімаючи проблему оптимізації педагогічної взаємодії, слід розглянути також відповідні форми організації навчального процесу, які сприятимуть розгортанню такої інтерактивної взаємодії. Серед таких методів ми можемо визначити евристичну бесіду, метод «круглого столу» і навіть деякі лекційні форми [8].

Щоб професійно-педагогічне спілкування було ефективним, викладачеві треба оволодіти психолого-педагогічною культурою спілкування, що відповідає принципу гуманізму, а саме:

- знати психологію студентського віку та психологічні особливості конкретної аудиторії;

- об'єктивно оцінювати поведінкові реакції, комунікативну активність окремих студентів, адекватно емоційно відгукуватися на них;

\section{Список літератури}

1. Голярдик Н. А. Педагогічне спілкування як фактор взаємодії викладача і студентів у вищих навчальних закладах / Н. А. Голярдик, Л. Л. Дика // Збірник наукових праць Національної академії державної прикордонної служби України. Серія «Педагогічні та психологічні науки». - 2014. - № 2 (71). - С. 64-73.
- уміти швидко організувати аудиторію і привернути її увагу до змісту заняття (прийоми самопрезентації, публічного виступу), залучати до активної навчальної роботи всіх студентів;

- вибирати такий спосіб своєї професійної поведінки, який найкраще відповідав би психологічним особливостям і психічному стану студентів;

- володіти прийомами стимулювання інтелектуальної ініціативи й пізнавальної активності студентів, умінням організовувати діалогічну взаємодію;

- своєчасно коригувати свій комунікативний задум відповідно до реальних умов педагогічної взаємодії;

- аналізувати процес педагогічного спілкування, встановлювати співвідношення мети, засобів і результатів комунікативної взаємодії [5, 8].

Висновки та перспективи подальших досліджень. Продуктивне спілкування в системі викладач - студент відбувається лише за умови організації педагогічного процесу на демократичних засадах, позитивного ставлення викладача до студентів, захопленості спільною творчою діяльністю. Важливу роль у цьому процесі відіграє здатність викладача збільшувати зацікавленість студентів-медиків до дисциплін, які вони вивчають, посилювати мотивацію студентів на здобуття освіти. Тому при організації взаємодії зі студентами на практичних заняттях викладачам варто використовувати найбільш продуктивні інтерактивні методи навчання. Необхідним $є$ індивідуальний підхід до студентів з метою розкриття їх внутрішнього потенціалу.

Таким чином, усвідомлення проблеми наявності бар’єрів педагогічного спілкування кожним викладачем дає можливість удосконалювати власну педагогічну майстерність та покращувати результати освітньої діяльності. У перспективі доцільним $€$ донесення до викладачів більше інформації про психологію спілкування із студентами, комунікативні проблеми та шляхи їх вирішення з метою забезпечення якості освітнього процесу та покращення результатів навчання.

2. Деркач Н. Я. Бар’єри в педагогічному спілкуванні / Н. Я. Деркач // Всеосвіта. - 2018 [Електронний ресурс]. - Режим доступу : https://vseosvita.ua/library/bareriv-pedagogicnomu-spilkuvanni-89882.html.

3. Козирєв М. П. Бар’єри педагогічного спілкування / М. П. Козирєв // Науковий вісник Львівського держав- 
ного університету внутрішніх справ. Серія психологічна. - 2013. - Вип. 2. - С. 136-146.

4. Повар А. Співробітництво викладача і студента в умовах інтеграції сучасних педагогічних технологій / А. Повар // Проблеми дидактики історії. - 2015. - Вип. 6. - C. 89-94.

5. Подоляк Л. Г. Психологія вищої школи : навч. посіб. для магістрантів і аспірантів / Л. Г. Подоляк, В. І. Юрченко. - К. : ТОВ «Філ-студія», 2006. - 320 с.

6. Роль викладача у системі «викладач - студент»: особливості спілкування / О. М. Камишний, I. О. Топол, А. М. Ліснича [та ін.] // Сучасні підходи до вищої медичної освіти в Україні : матеріали XIV Всеукр. наук.практ. конф. $з$ міжнар. участю, присвяч. 60-річчю ТДМУ (Тернопіль, 18-19 трав. 2017 р.) : у 2 т. - Тернопіль : ТДМУ, 2017. - Т. 2. - С. 56-57.

\section{References}

1. Holiardyk, N.A., \& Dyka, L.L. (2014). Pedahohichne spilkuvannia yak faktor vzaiemodii vykladacha i studentiv u vyshchykh navchalnykh zakladakh [Pedagogical communication as a factor of interaction of a teacher and students in higher educational institutions]. Zbirnyk naukovykh prats. Natsionalnoi akademii derzhavnoi prykordonnoi sluzhby Ukrainy/Seriia: pedahohichni ta psykholohichni nauky - Collection of scientific works of the National Academy of the State Border Guard Service of Ukraine. Series: Pedagogical Sciences, 2 (71), 64-73 [in Ukrainian].

2. Derkach, N.Ia. (2018). Bariery v pedahohichnomu spilkuvanni [Barriers to pedagogical communication]. Vseosvita - Education. Retrieved from: https://vseosvita. ua/library/bareri-v-pedagogicnomu-spilkuvanni-89882. html [in Ukrainian].

3. Kozyrev, M.P. (2013). Bariery pedahohichnoho spilkuvannia [Pedagogical communication barriers]. Naukovyi visnyk Lvivskoho derzhavnoho universytetu vnutrishnikh sprav. seriia psykholohichna - Bulletin of the Lviv State University of Internal Affairs. Psychological Series, 2, 136146 [in Ukrainian].

4. Povar, A. (2015). Spivrobitnytstvo vykladacha i studenta v umovakh intehratsii suchasnykh pedahohichnykh tekhnolohii [Cooperation of the teacher and the student in the conditions of integration of modern pedagogical technologies]. Problemy dydaktyky istorii - Problems of Didactics of History, 6, 89-94 [in Ukrainian].

5. Podoliak, L.H., \& Yurchenko, V.I. (2006). Psykholohiia vyshchoi shkoly: Navchalnyi posibnyk dlia mahistrantiv i aspirantiv [Higher school psychology: A manual for graduate students and postgraduate students]. Kyiv [in Ukrainian].

6. Kamyshnyi, A.M., Topol, I.A., Lesnichaia, A.N., Polischuk, N.N., \& Voitovych, A.V. (2017). Rol vykladacha
7. Старовойтенко Н. В. До проблеми педагогічної комунікативної взаємодії викладача зі студентами в умовах навчально-виховного процесу вищого навчального закладу / Н. В. Старовойтенко, О. П. Лещинський, T. М. Рига // Наукові записки Національного університету «Острозька академія». Серія «Психологія і педагогіка». - 2014. - Вип. 27. - С. 141-144.

8. Ткачук Т. Л. Психологічні особливості педагогічної взаємодії викладача та студентів / Т. Л. Ткачук // Вісник Харківського національного педагогічного університету імені Г. С. Сковороди. Психологія. - 2016. - Вип. 52. C. $159-166$.

9. Філоненко М. М. Психологія спілкування : підручник / М. М. Філоненко. - К. : Центр учбової літератури, 2008. - 224 c.

u systemi “vykladach-student”: osoblyvosti spilkuvannia [The role of the teacher in system "teacher-student": some aspects of communication]. Suchasni pidkhody do vyshchoi medychnoi osvity v Ukraini: materialy XIV Vseukrainskoi naukovo-praktychnoi konferentsii z mizhnarodnoiu uchastiu, prysviachena 60-richchiu TDMU - Modern Approaches to Higher Medical Education in Ukraine: Materials of XIV All-Ukrainian. Research Practice Conf. with the International Participation devoted to 60th Anniversary of TDMU, Ternopil, 2, 56-57 [in Ukrainian].

7. Starovoitenko, N.V., Leshchynskyi, O.P., \& Ryha, T.N. (2014). Do problemy pedahohichnoi komunikatyvnoi vzaiemodii vykladacha zi studentamy v umovakh navchalnovykhovnoho protsesu vyshchoho navchalnoho zakladu [The problem of teaching communicative interaction between teacher and students in terms of the educational process of higher education institution]. Naukovi zapysky Natsionalnoho universytetu "Ostrozka akademiia”. Seriia : Psykholohiia i pedahohika - Scientific Notes of the National University of Ostroh Academy. Series "Psychology and Pedagogy”, 27, 141-144 [in Ukrainian].

8. Tkachuk, T.L. (2016). Psykholohichni osoblyvosti pedahohichnoi vzaiemodii vykladacha ta studentiv [Psychological peculiarities of pedagogic interaction between the lecturer and students]. Visnyk Kharkivskoho natsionalnoho pedahohichnoho universytetu imeni H.S. Skovorody. Psykholohiia - Bulletin of the Kharkiv National Pedagogical University named after H.S. Skovoroda. Psychology, 52, 159-166 [in Ukrainian].

9. Filonenko, M.M. (2008). Psykholohiia spilkuvannia. Pidruchnyk [Psychology of communication. Textbook]. Kyiv [in Ukrainian]. 